\title{
Pemberdayaan Kelompok Tani Desa Jatimalang, Kabupaten Pacitan melalui Pelatihan Pembuatan Pupuk Organik
}

\section{(Empowerment of Famer Group of Jatimalang Village, Pacitan District through Training on Organic Fertilizer)}

\author{
Heri Wijayanto ${ }^{1}$, Didik Riyanto ${ }^{2}$, Bambang Triyono ${ }^{3}$, Hakas Putri Wikan Estu ${ }^{4}$ \\ 1 Prodi Manajemen Fakultas Ekonomi, Universitas Muhammadiyah Ponorogo, Universitas Muhammadiyah Ponorogo, \\ Jl. Budi Utomo No.10, Ronowijayan, Siman, Kabupaten Ponorogo, Jawa Timur 63471. \\ 2 Prodi Teknik Elektro Fakultas Teknik, Universitas Muhammadiyah Ponorogo, Jl. Budi Utomo No.10, Ronowijayan, \\ Siman, Kabupaten Ponorogo, Jawa Timur 63471. \\ 3 Prodi Ilmu Pemerintahan Fakultas Ilmu Sosial dan Ilmu Pemerintahan Universitas Muhammadiyah Ponorogo, \\ Jl. Budi Utomo No.10, Ronowijayan, Siman, Kabupaten Ponorogo, Jawa Timur 63471. \\ ${ }^{4}$ Sekolah Pascasarjana Ilmu Ekonomi, Fakultas Ekonomi dan Bisnis, Universitas Airlangga, Jl. Airlangga No.4-6, Airlangga, \\ Kecamatan Gubeng, Kota Surabaya, Jawa Timur 60115. \\ *Penulis Korespondensi: ok_coi@yahoo.com \\ Diterima Juni 2018/Disetujui Maret 2019
}

\begin{abstract}
ABSTRAK
Kelompok tani Lestari II Desa Jatimalang, Kecamatan Arjosari, Kabupaten Pacitan mempunyai potesi dalam produksi pupuk organik hal ini karena didukung oleh sisa hasil pertanian (jerami, batang pohon jagung, batang kedelai, dan lain-lain), dan limbah peternakan (kotoran hewan) yang melimpah. Pemanfaatan limbah pertanian maupun peternakan masih belum maksimal. Pengolahan limbah pertanian dan peternakan menjadi kompos yang dilakukan oleh sebagian besar petani di Desa Jatimalang belum menggunakan proses fermentasi, sehingga hasilnya dan kualitasnya kurang maksimal. Tujuan kegiatan pemberdayaan kelompok tani ini adalah memberikan pengetahuan tentang proses pembuatan pupuk organik dari penyedian bahan baku, pembuatan bio-aktivator, dan pengemasan hasil produksi. Metode yang digunakan dengan pelatihan terstruktur dan praktik langsung pembuatan pupuk organik. Hasil yang diperoleh dari kegiatan pemberdayaan ini adalah kelompok tani mampu membuat pupuk organik secara mandiri dengan kualitas hasil produksi yang cukup baik, namun pada proses pengadukan masih belum merata sehingga butiran-butiran pupuk organik besarnya tidak sama.
\end{abstract}

Kata kunci: kelompok tani Lestari II, pemberdayaan, pupuk organik

\begin{abstract}
The farmer group of Lestari II, Jatimalang Village, Arjosari Subdistrict, Pacitan Regency has potential in the production of organic fertilizer because it is supported by agricultural residues (straw, corn stalks, soybean stalks, etc.), and livestock waste (animal waste) overflow. Utilization of agricultural and livestock waste is still not optimal. Processing of agricultural and livestock waste into compost carried out by most farmers in Jatimalang Village has not used the fermentation process, so the results and quality are not optimal. The purpose of this farmer group empowerment activity is to provide knowledge about the process of making organic fertilizers from providing raw materials, making bio-activators, and packaging the results of products. The method used is structured training and direct practice of making organic fertilizer. The results obtained from this empowerment activity are that farmer groups are able to make organic fertilizers independently with good quality products, but the stirring process is still not evenly distributed so the granules of organic fertilizer are not the same size.
\end{abstract}

Keywords: empowerment, Lestari II farmer group, organic fertilizer

\section{PENDAHULUAN}

Masalah yang dihadapi oleh petani desa Jatimalang adalah masalah pupuk. Pupuk bersubsidi sangat terbatas dengan harga yang relatif tinggi, sehingga perlu alternatif pengganti pupuk kimia untuk memenuhi kebutuhan petani, sekaligus upaya mengurangi ketergantungan pada penggunaan pupuk kimia (Wijayanto et al. 2018). Penggunaan pupuk kimia dalam jangka waktu lama dan berlebihan akan merusak struktur tanah (Lestari 2009). Pertanian organik sudah lama dikenal oleh manusia, yakni sejak 
ilmu bercocok tanam diterapkan oleh nenek moyang kita (Roidah 2013).

Pemakaian berimbang antara pupuk organik dan anorganik terbukti mampu meningkatkan hasil tanaman (Minardi et al. 2014). Pupuk organik diperlukan untuk membantu pemulihan kesuburan tanah. Efisiensi dan efektivitas penyerapan unsur hara tanaman pada tanah tidak akan berjalan lancar karena efektivitas penerapan unsur hara sangat dipengaruhi oleh kadar bahan organik dalam tanah (Yuniwati et al. 2012).

Salah satu solusi menanggulangi dampak negatif tersebut adalah penggunaan pupuk organik (Asngad 2013). Penggunaan pupuk organik semakin meningkat seiring dengan maraknya pertanian organik, sementara pembuatan pupuk organik membutuhkan waktu yang cukup lama dan rumit jika dikerjakan secara manual (Hasman et al. 2015)

Sisa hasil pertanian di Desa Jatimalang seperti jerami, daun singkong, bongkol jagung, dan dedaunan lainnya sangat melimpah. Pemanfaatannya sisa hasil pertanian tersebut belum optimal, karena baru 30\% yang dimanfaatkan untuk pakan ternak, dan selebihnya dibakar atau dibuang secara percuma (Wijayanto et al. 2018). Pengomposan limbah-limbah pertanian secara alami membutuhkan waktu 3-4 bulan lebih, sedangkan masa tanam yang mendesak menjadikan pupuk organik buatan petani kurang ekonomis dan tidak efisien.

Percepatan implementasi pertanian organik dapat dilakukan melalui kebijakan pemakaian jerami secara bijak (Darwis \& Rachman 2013). Limbah pertanian seperti jerami, sampah perkotaan seperti kertas dan sayuran, serta sampah perumahan seperti daun dan potongan rumput merupakan sumber bahan organik yang sangat potensial untuk menyuburkan tanah dan berperan penting terhadap perbaikan sifat fisik, kimia, dan biologi tanah, serta mengefisienkan penggunaan pupuk anorganik (Hartatik et al. 2015)

Penggunaan pupuk organik dalam jangka panjang dapat meningkatkan produktivitas lahan dan dapat mencegah degradasi lahan sehingga penggunaannya dapat membantu upaya konservasi tanah yang lebih baik (Puspadewi \& Kusumawati 2016). Pemanfaatan limbah pertanian dipadukan dengan limbah peternakan menjadi pupuk organik merupakan harapan masyarakat Desa Jatimalang, agar mampu meningkatkan produksi pertanian melalui pupuk organik, sekaligus kesehatan hewan-hewan peliharaan terjaga yang berakibat pada meningkatnya produktivitas peternakan. Tujuan kegiatan pemberdayaan kelompok tani ini adalah memberikan pengetahuan tentang proses pembuatan pupuk organik dari penyedian bahan baku, pembuatan bio-aktivator, dan pengemasan hasil produksi. Program pemberdayaan masyarakat ini diharapkan kelompok tani mampu memanfaatkan sisa pertanian dan peternakan menjadi pupuk organik yang berkualitas, sehingga ketercukupan kebutuhan pupuk untuk memenuhi kebutuhan petani dapat terpenuhi.

\section{METODE PELAKSANAAN KEGIATAN}

\section{Lokasi dan Partisipan Kegiatan}

Kegiatan pengabdian kepada masyarakat dilaksanakan di Desa Jatimalang, Kecamatan Arjosari, Kabupaten Pacitan. Partisipan sekaligus mitra yang dilibatkan dalam pelaksanaan kegiatan adalah kelompok tani Lestari II yang beranggotakan sebanyak 33 orang yang diketuai oleh Subasri Haryono. Peserta program pelatihan berjumlah 15 orang yang terdiri dari 13 orang laki-laki dan 2 orang perempuan.

\section{Bahan dan Alat}

Bahan yang dibutuhkan untuk pembuatan pupuk organik di antaranya jerami, kotoran hewan, batang pohon pisang, EM4, dedak, bubuk gergaji, arang sekam, dan daun-daunan. Alat yang digunakan untuk memproses bahan baku menjadi pupuk organik di antaranya mesin granulator, mesin pencacah daun-daunan dan kotoran hewan, pengayak, dan pengaduk.

\section{Metode Pelaksanaan}

Alur metode pelaksanaan kegiatan pemberdayaan kelompok tani Lestari II diawali dengan penyampaian materi tentang manfaat pupuk organik, kekurangan dan kelebihan pupuk organik, peluang, dan strategi pemasaran pupuk organik, dilanjutkan praktik pembuatan pupuk organik. Alur pembuatan diawali dengan penyiapan bahan baku, dilanjutkan proses pengolahan yang meliputi: mencacah limbah pertanian dan peternakan, menambahkan starter bio-aktivator, mencampur bahan, dan penyimpanan. Terakhir adalah proses finishing dan pengemasan hasil produksi. Detail alur sebagaimana dalam Gambar 1.

Keberhasilan pelaksanaan program dinilai dengan dua cara, yaitu untuk penilaian pengetahuan tentang pupuk organik dinilai secara 
perorangan dengan tes lisan dan tulis dengan nilai A (nilai 85-100), B (nilai 75-84), C (nilai 6074), dan D (nilai 0-59). Penilaian praktik pembuatan pupuk dilakukan secara kelompok dengan menilai hasil produksi pupuk, dengan nilai sangat baik, baik, dan kurang.

\section{HASIL DAN PEMBAHASAN}

\section{Pelaksanaan Kegiatan}

Penyampaian materi tentang manfaat pupuk organik, kekurangan dan kelebihan pupuk organik, peluang, dan strategi pemasaran pupuk organik disampaikan oleh tim pelaksana kegiatan pengabdian, dan pakar pembuatan pupuk organik, yaitu bapak Rahardi Subarno yang sudah memproduksi pupuk organik lebih dari 5 tahun. Peserta, instruktur, dan tim pelatihan pembuatan pupuk organik terlihat pada dan penyampaian materi pembuatan pupuk organik terlihat pada Gambar 2.

Praktik pembuatan pupuk organik, diawali dengan penyiapan bahan baku (kotoran ternak, jerami, arang sekam, batang pohon pisang, dan tape), pengecekan kesiapan peralatan yang akan digunakan, yaitu mesin pencacah, pengayak, dan granulator (Gambar 3). Proses pembuatan pupuk kompos organik adalah sebagai berikut:

- Siapkan media pembuatan pupuk ditempat yang sejuk dan tidak terkena matahari langsung serta tidak kena hujan, larutkan EM4 dan gula ke dalam air.

- Lapisan pertama, campurkan kotoran ternak dengan arang sekam kemudian aduk hingga merata, setelah itu taburkan dekomposer (EM4 dan gula yang sudah dilarutkan dalam air) secukupnya aduk hingga merata.

- Lapisan kedua taburkan jerami, dedak, bubuk gergaji, dan bahan-bahan organik lainnya hingga merata kemudian siram dengan dekomposer.

- Tutup rapat tumpukan bahan dengan menggunakan karung goni dan jerami.

- Lakukan monitoring setiap pagi dan sore, dengan cara memasukan tangan (dengan sarung tangan) jika tangan kita tidak kuat menahan panas adonan maka adonan belum siap dipakai. Aduk setiap melakukan monitoring.

- Biasanya hari keempat adonan sudah siap, cara mengeceknya masukan tangan anda jika merasakan panas pada adonan maka pupuk kompos organik siap dipakai.

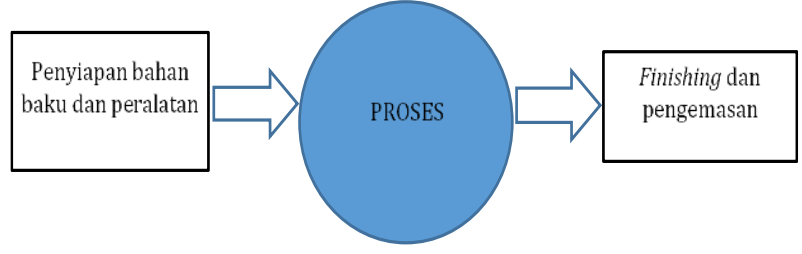

Gambar 1 Alur pelaksanaan pembuatan pupuk organik.

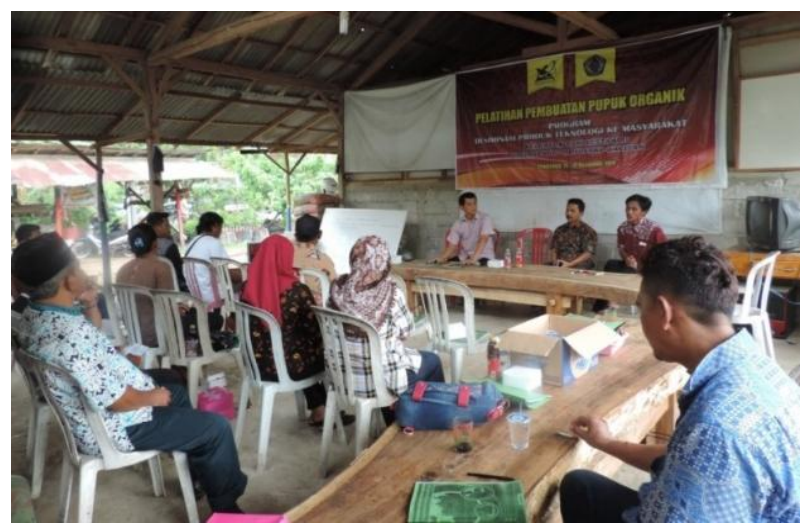

Gambar 2 Penyampaikan materi pembuatan pupuk organik.
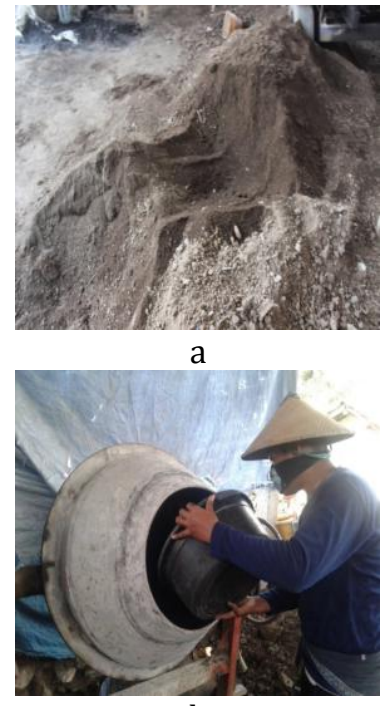

b

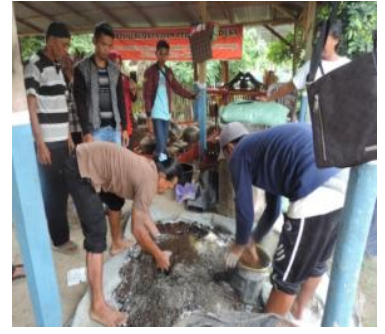

C

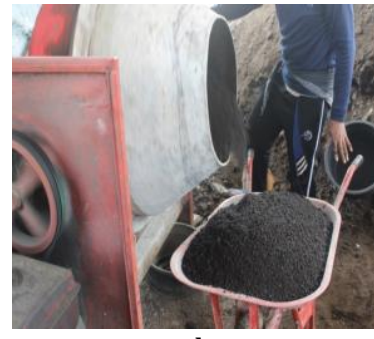

d



e

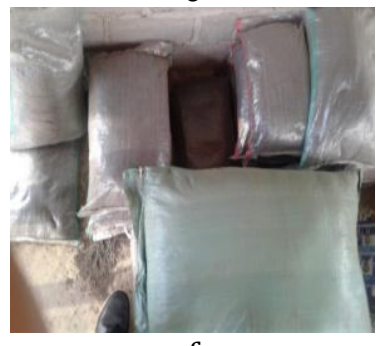

f
Gambar 3 Tahap pembuatan pupuk kompos organik, a) Pengadukan bahan-bahan secara manual; b) Pengadukan bahan-bahan dengan mesin; c) Praktik pencampuran bahan; d) Hasil adukan bahan-bahan; e) Pupuk organik produksi mesin; dan f) Pengepakan pupuk organik. 


\section{Analisis Hasil Kegiatan}

Kegiatan yang dilakukan dalam program pengabdian ini terdiri dari dua tahap, yaitu penguatan pengetahuan tentang pupuk organik dan pelatihan pembuatan pupuk organik. Hasil kegiatan penguatan pengetahuan tentang pupuk organik menunjukkan nilai yang sangat baik, dilihat dari nilai A (85-100) merupakan nilai yang paling banyak diperoleh oleh peserta untuk setiap aspek yang dinilai, sebagaimana Tabel 1. Aspek penilaian yang paling baik adalah pemahaman tentang bahan baku pupuk organik, hal ini dimungkinkan melimpahnya bahan baku di lingkungan Desa Jatimalang sehingga peserta dengan mudah memahami.

Hasil evaluasi pada tahap praktik pembuatan pupuk organik secara kelompok menunjukkan bahwa pada proses pencahan bahan baku dan pencampuran diperoleh hasil sangat baik, artinya bahwa kualitas hasil proses pencacah dan penyampuran bahan baku yang dilakukan oleh peserta pelatihan sesuai atau sama dengan yang dilakukan instruktur (Tabel 2). Proses granulasi dan pengemasan diperoleh hasil baik, artinya bahwa kualitas yang dihasilkan secara umum cukup baik, namun ukuran granul pupuk yang dihasilkan belum sama dan pengemasan yang masih kurang rapi. Evaluasi terhadap proses pembuatan starter menunjukkan bahwa kelompok tani masih kurang dalam memahami proses pembuatan bio-aktivator pupuk organik (Gambar 4). Hal ini dikarenakan kerumitan dan perlunya pengalaman yang cukup untuk menghasilkan bio-aktivator yang baik.

\section{Kendala yang dihadapi}

Kendala yang dihadapi mitra dalam pembuatan pupuk organik adalah ketika musim penghujan, bahan baku terutama kotoran hewan kondisinya basah sehingga untuk proses pencacah harus menunggu kering dulu. Kendala lainnya adalah pembuatan starter yang belum maksimal berhasil karena perlunya pengalaman dan ketelitian di dalam penyampuran bahan.

\section{Dampak Kegiatan}

Dampak bagi kelompok tani Lestari II Desa Jatimalang adalah kelompok tani mampunyai usaha sampingan, yaitu pembuatan pupuk organik dengan mamanfaatkan limbah pertanian dan peternakan yang melimpah. Limbah yang selama ini dibuang dan memberikan dampak kurang baik bagi lingkungan (bau kotoran hewan dan polusi udara akibat limbah pertanian dibakar) menjadi limbah yang bermanfaat dan memberikan penghasilan tambahan bagi petani. Limbah pertanian yang pada awalnya dibakar dan dibuang, setelah ada kegiatan pemberdayaan kelompok tani maka $75 \%$ sisa limbah pertanian dimanfaatkan untuk bahan pupuk organik dan $25 \%$ dibakar di pematang sawah untuk membunuh gulma.

Limbah perternakan yang pada awalnya ditumpuk dan menghasilkan bau yang tidak sedap, dengan adanya kegiatan pemberdayaan kelompok tani memprakarsai petani di sekitar Desa Jatimalang untuk mengolah kotoran hewan menjadi pupuk organik. Kotoran hewan yang berhasil diolah menjadi pupuk organik setelah kegiatan pemberdayaan sebesar $30 \%$, sedangkan sebesar $70 \%$ belum bisa diolah karena keterbatasan peralatan dan jumlah kotoran hewan sudah melimpah (lebih 1 tahun ditumpuk dan tidak dimanfaatkan). Diharapkan dengan pengetahuan baru tentang pengolahan limbah menjadi pupuk organik petani mampu membuat pupuk organik secara mandiri dengan kualitas yang baik.

Produksi pupuk organik kelompok tani Jatimalang sebelum adanya kegiatan pemberdayaan sebanyak $500 \mathrm{~kg}$ dalam 1 tahun. Kualitas pupuk organik yang dihasilkan dalam bentuk olahan sederhana tanpa menggunakan bio-aktivator sehingga kurang baik kualitasnya, ditandai dengan kadar air yang tinggi, bau yang menyengat, dan hasil fermentasi yang tidak merata. Pelatihan yang diselenggarakan berdampak pada peningkatan hasil produksi pupuk organik sebanyak $200 \%$ atau sebanyak

Table 1 Hasil evaluasi pada tahap penguatan pengetahuan tentang pupuk organik (jumlah peserta 15 orang)

\begin{tabular}{|c|c|c|c|c|c|c|c|c|}
\hline \multirow{3}{*}{ Aspek yang dinilai } & \multicolumn{8}{|c|}{ Penilaian } \\
\hline & \multicolumn{2}{|c|}{$\mathrm{A}(85-100)$} & \multicolumn{2}{|c|}{$\mathrm{B}(75-84)$} & \multicolumn{2}{|c|}{$\mathrm{C}(60-74)$} & \multicolumn{2}{|c|}{$\mathrm{D}(0-59)$} \\
\hline & Jumlah & $\%$ & Jumlah & $\%$ & Jumlah & $\%$ & Jumlah & $\%$ \\
\hline Pemaham & 10 & 66,6 & 4 & 26,7 & 1 & 6,7 & 0 & 0 \\
\hline Kandungan pupuk organik & 8 & 53,3 & 3 & 20,0 & 4 & 26,7 & 0 & 0 \\
\hline Manfaat pupuk organik & 8 & 53,3 & 4 & 26,7 & 3 & 20,0 & 0 & 0 \\
\hline Kekurangan dan kelebihan & 12 & 80,0 & 3 & 20,0 & 0 & 0 & 0 & 0 \\
\hline Bahan baku pupuk organik & 13 & 86,7 & 2 & 13,3 & 0 & 0 & 0 & 0 \\
\hline
\end{tabular}


Tabel 2 Hasil evaluasi pada tahap praktik pembuatan pupuk organik

\begin{tabular}{ll}
\hline \multicolumn{1}{c}{ Aspek yang dinilai } & \multicolumn{1}{c}{ Keterangan } \\
\hline Proses pencacah & Sangat baik \\
Proses pembuatan starter & Kurang \\
Proses pencampuran & Sangat baik \\
Proses granul & Baik \\
Pengemasan & Baik \\
\hline
\end{tabular}

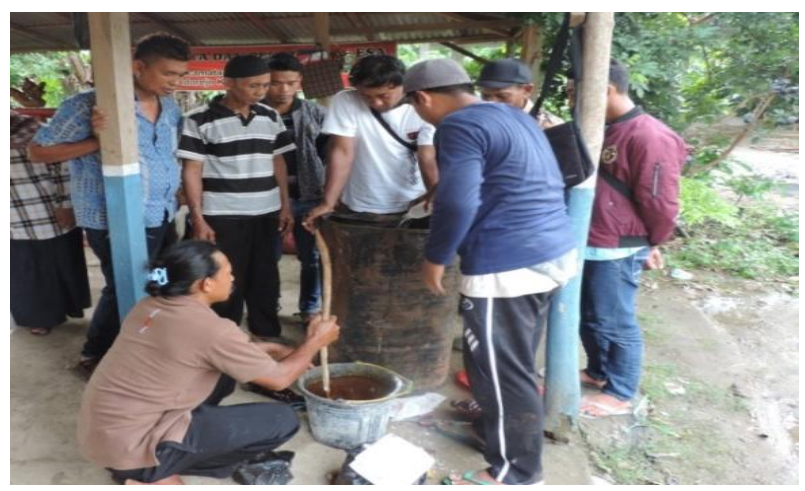

Gambar 4 Pembuatan starter bio-aktivator pupuk organik.

$1.000 \mathrm{~kg}$, dengan kualitas yang lebih baik, dicirikan kadar air yang rendah, tidak berbau, dan fermentasi yang merata.

\section{Upaya Keberlanjutan Program}

Upaya tim pengabdi untuk menjaga keberlanjutan program, dilakukan pemantauan, dan pendampingan secara terus menerus. Tujuan pendampingan berkelanjutan untuk peningkatan kualitas hasil produksi, memberikan pelatihan pembukuan, dan strategi pemasaran. Perlunya peningkatan pengetahuan tentang unsur-unsur pupuk organik untuk memberikan semangat kepada kelompok tani yang lain yang belum menggunakan pupuk organik. Pemanfaatan pupuk organik perlu berkelanjutan dan terus dilakukan hal ini dikerenakan pupuk organik tidak bisa langsung aktif seperti halnya pupuk kimia.

\section{SIMPULAN}

Pelaksanaan program desiminasi produk teknologi ke masyarakat melalui kegiatan pelatihan pembuatan pupuk organik bagi kelompok tani Lestari II Desa Jati Malang, Arjosari, Kabupaten Pacitan dapat meningkatkan pengetahuan pembuatan pupuk organik. Pelatihan yang diikuti oleh sebagian besar anggota kelompok tani dapat berjalan sesuai dengan harapan dan target yang ditetapkan, yaitu peserta mampu mem- praktikkan pembuatan pupuk organik dari proses penyiapan bahan, proses pembuatan, dan pengemasan. Hasil produksi pupuk organik dari pelatihan yang dilaksanakan menurut tim pengabdian dan tim ahli yang memberikan materi, dinilai baik dan hampir sama dengan kualitas yang diproduksi oleh tenaga ahli. Kekurangan yang nampak adalah pada proses penyampuran bahan baku pupuk organik belum maksimal, ditandai dengan hasil butiran-butiran pupuk organik belum sama atau belum merata besar-kecilnya. Penyiapan starter atau bioaktivator pupuk organik belum sempurna hasilnya, hal ini dikerenakan proses pembuatan bio-aktivator yang singkat, dan penyiapan bahan penampungan yang kurang bersih dan maksimal.

Kelompok tani Lestari II, Desa Kalimalang, Kecamatan Arjosari, Kabupaten Pacitan dengan adanya program desiminasi produk teknologi ke masyarakat melalui kegiatan pelatihan pembuatan pupuk organik mendapatkan ilmu baru tentang pembuatan pupuk organik di Star Baruno Organik Ponorogo. Ilmu yang diperoh di antaranya cara membuat bio-aktivator, pupuk organik padat (POP), dan pupuk organik cair (POC).

\section{DAFTAR PUSTAKA}

Asngad A. 2013. Inovasi Pupuk Organik Kotoran Ayam Dan Eceng Gondok Dikombinasi dengan Bioteknologi Mikoriza Bentuk Granul. Jurnal MIPA. 36(1): 1-7.

Darwis V, Rachman B. 2013. Potensi pengembangan pupuk organik In-Situ mendukung percepatan penerapan pertanian organik". Forum penelitian Agro Ekonomi. 31(1): 51-65. https://doi.org/10.21082/ fae.v31n1.2013.51-65

Hartatik W, Husnain, Widowati LR. 2015. Peranan pupuk organik dalam peningkatan produktivitas tanah dan tanaman. Jurnal Sumberdaya Lahan. 9(2): 107-120.

Hasman E, Naswir, Irwan. 2015. Rancang Bangun Mesin Pembuat Pupuk Organik Granular Tipe Screw. Jurnal Teknologi Pertanian Andalas. 19(2): 25-28.

Lestari AP. 2009. Pengembangan pertanian berkelanjutan melalui substitusi pupuk Anorganik dengan pupuk organik. Jurnal Agronomi. 13(1): 38-47. 
Minardi, Hartati S, Pardono, 2014. Imbangan Pupuk Organik dan Anorganik Pengaruhnya Terhadap Hara Pembatas dan Kesuburan Tanah Lahan Sawah Bekas Galian C pada Hasil Jagung (Zea mays L). Jurnal Ilmu Tanah dan Agroklimatologi. 11 (2): 122-129.

Puspadewi S, Sutari W, Kusumiyati. 2016. Pengaruh konsentrasi pupuk organik cair (PO) dan dosis pupuk N, P, K terhadap pertumbuhan dan hasil tanaman Jagung Manis (Zea Mays L.Var Rugosa Bonaf) Kultivar Telenta. Jurnal Kultivasi. 15(3): 208-216. https://doi.org/10.24198/kltv.v15i3.11764

Roidah IS. 2013. Manfaat penggunaan pupuk organik untuk kesuburan tanah. Jurnal
Universitas Tulungagung BONOROWO. 1(1): 30-43.

Wijayanto H, Riyanto D, Triono B. 2018. Desiminasi Produk Teknologi Mesin Pengolah Pupuk Organik Desa Jati Malang Kecamatan Arjosari Kabupaten Pacitan. Wikrama Parahita Jurnal Pengabdian Masyarakat. 2(1): 1-5. https://doi.org/10.30656/jpmwp.v2i1. 526

Yuniwati M, Iskarima F, Padulemba A. 2012. Optimasi Kondisi Proses Pembuatan Kompos dari Sampah Organik dengan cara Fermentasi Menggunakan EM4. Jurnal Teknologi. 5(2): 172-181. 